\section{Gordiuk M., \\ Semynoh M., \\ Holodnov 0., \\ Thachuk I., \\ Ivanov B.}

\title{
DETERMINATION OF REMAINING RESOURCE OF CONSTRUCTIONS OF BUILDINGS AFTER DIFFERENT INFLUENCES
}

Об'єктом дослідження є залишковий ресурс конструкцій будівель та споруд після різних впливів. Залишковим ресурсом називається сумарне напрацювання об'єкту від моменту контролю його технічного стану до переходу в граничний стан.

Методики розрахунку, які рекомендовано чинними нормативними документами України, не дозволяють прогнозувати імовірність відмов, збільшення кількості дефектів і деформацій конструкцій в часі та реально оцінити можливість подальшої експлуатацї за таких умов. Одним з найбільш проблемних місць є визначення технічного стану конструкцій будівель та споруд, які працюють при різних впливах (в агресивному середовищі, при вимушених зміщеннях опор, можливих високотемпературних впливах тощо).

Показано, що залишковий ресурс конструкиій будівель та споруд, які отримали пошкодження під час експлуатацї̈ після різних впливів, може бути перепризначеним за рахунок підсилення. При цьому основним питанням залишається визначення фізико-механічних характеристик матеріалів, які було застосовано при виготовленні конструкцій, а також виконання розрахунку конструкцій для обгрунтованого призначення перерізів елементів підсилення. Характеристики матеріалів визначаються під час проведення обстежень. В ході обстеження використовуються різні методи визначення фізико-механічних характеристик матеріалів конструкцій (бетону, арматури, сталі, цегляної кладки тощо), як правило, неруйнівні. Руйнівні методи можливо застосовувати в тих випадках, коли це можливо за умов роботи конструкцій, наприклад, вилучення фрагментів металу, арматури або бетону з малонавантажених елементів.

Можливість перепризначення залишкового ресурсу визначається шляхом зіставлення величин несучої здатності конструкцій з тими величинами, що діють. Несучу здатність конструкцій визначають з використанням величин характеристик матеріалів і параметрів (розмірів поперечних перерізів, геометричних розмірів з урахуванням корозійного зносу тощо), які було отримано під час проведення обстеження. Величини зусиль, що діють в конструкціях будівель та споруд, визначаються шляхом моделювання їхної роботи з використанням методу скінченних елементів і сучасних обчислювальних комплексів. Завдяки такій процедурі можна отримати зусилля, які могли б виникнути в конструкціях будівлі та підсилення. Завдяки цьому забезпечується можливість прийняття рішення про перепризначення залишкового ресурсу конструкцій, тобто можливість подальшої експлуатацї, необхідність підсилення або заміни.

Ключові слова: конструкиї будівель та споруд, дефекти та пошкодження, обстеження, розрахунок конструкцій, залишковий ресурс.

Received date: 11.06.2019

Accepted date: 27.06 .2019

Published date: 31.10 .2019
Copyright (c) 2019, Gordiuk M., Semynoh M., Holodnov O., Tkachuk I., Ivanov B. This is an open access article under the CC BY license (http://creativecommons.org/licenses/by/4.0)

\section{Introduction}

Together with new construction, more and more often there is a need to carry out work to restore the operational suitability of building structures of buildings and structures. In this case, it is necessary to resolve issues related to the determination of the stress-strain state (SSS) and the implementation of work to extend the life of structures.

These works must be solved in a complex, that is, a forecast of a possible extension of the life of structures of buildings and structures should be preceded by work related to the assessment of their technical condition. These works are carried out in accordance with the requirements of current regulatory documents [1-3].
Assessment of the technical condition is carried out on the basis of the results of previously performed and current observations, verification calculations, and the like. Verification calculations are performed, as a rule, using simplified calculation schemes without taking into account the actual state of structures and the prediction of property degradation. This approach does not allow simulating the SSS of structures in the dynamics of the development of degradation processes and does not make it possible to make the right decision on the composition of measures to ensure further reliable and safe operation of structures [4, 5].

The work is one of the stages of research on the problem of extending the life of building structures of buildings and structures under the condition of both power and other (corrosive, thermal, deformation, etc.) effects. 


\section{The object of research and its technological audit}

The object of research is the residual resource of the structures of buildings and structures after various influences. The residual resource is the total operating time of the object from the moment of monitoring its technical condition to the transition to the limit state.

For building structures, a unified classification (nomenclature) of possible technical conditions is established, the number of which is accepted four in accordance with [1].

Structures and elements from the very beginning of their operation throughout the entire life cycle due to aging and degradation can sequentially be in each of the four technical states. Establishing in which of the indicated technical conditions a given design and element is located is the task of a set of works to assess their technical condition.

Elements of a structure or structure may be in different states. In this case, the state of the structure or structure as a whole is taken according to the worst state in accordance with [1].

The determination of the current technical condition together with the forecast of its change in time can't be performed without preliminary observations.

General monitoring of the technical condition of buildings and structures is a system of planned, continuous or periodic observations and control. These activities are carried out according to a specially developed program for determining changes in the technical condition of buildings and structures and evaluating them in order to prevent the limiting values of controlled parameters. This term refers to the maximum (minimum) values of the monitored parameters used to configure the monitoring system and intended to assess changes in the state of load-bearing structures of an object [2].

The guidance DSTU-N B V.1.2-17:2016 [2] applies to buildings and structures for classes of responsibility for the possible consequences of CC2, CC3 according to DBN V.1.2-14-2018 [3]. The guidance establishes general requirements for monitoring the technical condition of structural elements, buildings and engineering structures.

Guidelines DSTU-N B V.1.2-17:2016 [2] defines the controlled parameters of various types of monitoring the technical condition of building structures, buildings and structures at various stages of their life cycle: design, construction, operation, conservation, re-preservation, liquidation.

Guidelines DSTU-N B V.1.2-17:2016 [2] does not replace the obligation to fulfill the requirements of the construction process participants to ensure the quality of construction work, reliability and safety of buildings and structures provided for in the design documentation.

The basis of the organization of monitoring to ensure the operational safety of buildings and structures is to monitor changes in indicators of state parameters and assess certain changes.

The number and types of controlled parameters are determined by the results of a previous observation, the requirements of regulatory and design documentation, the conditions for maintaining the operational properties of an object during its life cycle.

The reliability of the obtained results must be ensured by the application of standardized methods for conducting research and determining controlled parameters, relevant instruments, equipment and measuring instruments.
As criteria for failures and damage, the limiting values of the parameters of the technical condition (the presence or absence of cracks, the width of the opening of cracks, deflections, displacements, strength and deformability of structural materials, etc.), which are usually set by design or regulatory documentation, should be considered.

Based on the established signs, using the predicted change over time, criteria are established for the exhaustion of the bearing capacity of structures with the consequences of this type of failure, and the residual resource is determined.

\section{The aim and objectives of research}

The aim of research is development of interrelated measures to determine the controlled parameters of reinforced concrete and steel structures obtained during monitoring, to determine their technical condition and residual life.

To achieve this aim, it is necessary to complete the following objectives:

1. To develop general requirements for monitoring the technical condition of structural elements, buildings and structures.

2. To develop methods for calculating the stress-strain state and assessing the condition of structures that have received defects and damage during operation.

3. To develop methods for determining the residual life of structures of buildings and structures based on monitoring results.

\section{Research of existing solutions of the problem}

In general, monitoring of construction objects is a system of monitoring their technical condition, receiving and transmitting information to services that are responsible for the safety of facilities. It is an independent element of the scientific and technical support of objects in the process of their construction and operation, ensures the reliability of construction objects and allows to predict their durability [2,6].

Monitoring indicators are the values of the static and dynamic characteristics of the structures of the object, and the monitoring itself is carried out according to specially developed programs. In an urgent respect, it is permanent or periodic, which is performed in accordance with the requirements of current regulatory documents in the following circumstances [3, 7]:

- the end of the regulatory life of the facility;

- identification of significant damage to the object that occurred during its operation;

- assessment of the possibility of using the facility for its main purpose after man-made and special influences (aggressive environment, high temperatures, etc.);

- change of purpose of the structure;

- at the request of state building control authorities.

Particularly important is the objectivity and efficiency of monitoring, the ability to evaluate with its help the current technical condition of the facilities and predict their durability, while eliminating the possibility of the transition of the facilities to an emergency state.

Important in practical terms can be considered the costeffectiveness of monitoring, the necessary level of professionalism of staff, the availability of information by users and the like. 
Among the main directions of solving this problem, which were found in the resources of world scientific periodicals, can be identified:

- taking into account temperature effects [8, 9];

- taking into account geometric non-linearity and non-

linear operation of structures [10, 11], it allows the construction of adequate design schemes, reduce material consumption, ensure structural safety, resistance to progressive collapse;

- taking into account, when calculating slabs, two variants of finite elements (SC) for modeling elements of steel-reinforced concrete floors [12,13], which made it possible to determine the deflections and displacements of structures.

In [14], a methodology for thermotechnical calculation of reinforced concrete structures and heat loss of a foundation slab with non-uniform temperature distributions of the internal temperature is presented. The determination of the strength and deformability of steel-reinforced concrete beams with various anchor stops and types of fire protection during three-sided heating is shown in $[15,16]$.

All the above works, with the exception of $[4,5]$, allow solving particular cases of structural analysis. The methods for determining the technical condition and residual life of structures after various influences are absent in the literature accessible to the authors, which makes the study promising.

\section{Methods of research}

The parameters of the impacts and their magnitudes are determined in accordance with the requirements of current regulatory documents [2, 3] according to observations of meteorological stations; on passports for equipment and other documents. The obtained parameter values are used in the calculations and design of the facility, and are also basic for monitoring its technical condition during construction and operation.

Reactions of changes in the technical condition of structural elements are recorded by sensors of the monitoring system, which allow to obtain data on the reaction of the object to external and internal influences, namely:

- movement of the object and individual elements in space in the form of deflections, sediments, rolls and the like;

- deformation in building structures;

- changes in the dynamic characteristics of building structures and the building as a whole;

- changes in the environment surrounding the monitoring object.

Monitoring of building structures is carried out on the basis of the approved program using technical means of non-destructive testing and the frequency established in the program. The frequency of work is determined taking into account the classes of responsibility of building structures in accordance with DBN V.1.2-14-2018 [3]. In this case, the minimum frequency of observations is established in accordance with the design and regulatory documents or special requirements for a particular object.

The monitoring results include information on the condition of the facility and the development area, which is provided in the interim and final reports. Reports are issued on the basis of registration, accumulation and initial analysis of information from sensitive elements, which are installed on building structures subject to control. Requirements for the composition of reports are established in the monitoring work program. Based on the results of monitoring observations, the report concludes on the current values of the controlled parameters of building structures. The monitoring results are used to assess the technical condition of building structures, buildings and structures. The final result of assessing the technical condition of building structures is the conclusion about the possibility (impossibility) of further operation of buildings and structures in normal mode.

Permanent monitoring of the technical condition of buildings and structures using automated systems is organized on structures that are responsible for safety criteria. In this case, instruments and equipment are used with automatic storage, processing and transmission of measurement results through information communication channels.

The limiting values of the parameters are evaluated according to the criteria of the state of the elements of buildings and structures that determine under what conditions it becomes impossible to perform their functions for technical reasons, which include the danger of destruction of individual elements, loss of general stability and the like.

Assessment of the technical condition parameters by their limit criteria are used to make decisions about:

- ensuring the safety of people;

- transfer of the facility to emergency operation, emergency response and minimization of possible consequences; - strengthening the supporting structures of the object.

The monitoring system of building structures consists of the following main elements:

- measuring elements of controlled parameters (measuring elements are sensors for recording changes in the state parameters of building structures. The measurement accuracy and the number of sensors are determined by the monitoring program);

- information system for registration, accumulation and primary processing of indicators of controlled parameters of building structures;

- mathematical model (or its automated analogue in the information system) for operational preliminary forecasting of the values of controlled parameters of building structures in the near future);

- systems for setting up and managing an information system for monitoring building structures.

The real-time information system provides the collection, accumulation, access, display and dissemination of data on the value of indicators of controlled parameters of building structures of buildings and structures.

\section{Research results}

The mathematical model of the building (or its automated analogue in the information system) makes it possible to carry out operational preliminary forecasting of the values of the controlled parameters of building structures. The result of the previous operational forecast is the conclusion about the operational suitability of controlled building structures, taking into account a possible tendency to worsen their technical condition. The forecast of the output of the recorded values of certain parameters of building structures of the limit of a given criterion is the basis for making decisions on the possibility of further operation of a building or structure [2]. 
The basis for assessing the technical condition of buildings and structures is information on finding controlled parameters in a given range of safe operation. The limiting measurement criteria for sensors that meet the safe operation of building structures are set in the Monitoring Program.

Determination of the residual life of structures of buildings and structures is carried out on the basis of data obtained as a result of monitoring. According to the results of the analysis of technical documentation, visual and instrumental examination, a preliminary assessment of the technical condition of structures, buildings and structures as a whole is carried out and a conclusion is made about the need for mathematical modeling of SSS or simplified structural calculations [5]. A preliminary assessment of the technical condition is based on the evaluation criteria. The forecast of changes in the technical condition during further operation is carried out on the basis of the analysis of degradation processes and the identification of the compliance of the actual parameters of the technical condition with the requirements of design and regulatory documentation.

The technical condition of structures in the absence of defects can be considered normal or satisfactory if they are not fulfilled $[4,5]$ :

- condition for failure of structures (condition for the structure to reach the limit states of the first group):

$$
F>F_{u}
$$

where $F, F_{u}$ - the values, respectively, of the most possible force during operation of the element from the calculated loads and the smallest bearing capacity;

- condition for the construction to reach the limit states of the second group:

$$
f>f_{u}
$$

where $f, f_{u}$ - the characteristic displacement of the structure (deflection, angle of rotation, roll, etc.), which are determined respectively as a result of calculation or examination and the limit is established by the norms.

The excessive or prolonged openings of cracks in reinforced concrete structures, as well as the achievement of the limiting values of the deflections, are considered as parameters of the limiting states of the second group, the achievement of which is considered as a failure-obstacle.

The limiting states of this group cause a temporary cessation or partial violation of the conditions of normal operation, but at the same time there is no clear boundary between the transition to the limiting state.

The functions of determining the bearing capacity are taken in accordance with the requirements of current regulatory documents. It is allows to apply direct restrictions of the following type to the change of structural, strength and other determining parameters:

$$
\begin{aligned}
& \delta_{\min } \leq \delta, \\
& R_{\min } \leq R,
\end{aligned}
$$

where $\delta_{\min }-$ the minimum permissible value of the intersection parameter of the reinforced concrete element (height, width, reinforcement area, etc.); $\delta$ - the actual value of the section parameter; $R_{\min }$ - the minimum allowable design resistance of the material (concrete, reinforcement); $R$ - the actual design resistance of the material.

Assessment of the technical condition is carried out by comparing the controlled parameters with the corresponding design parameters or determined as a result of observations and calculations. Structures can go to the limit state if parameters such as:

- geometric dimensions (reduction as a result of corrosion wear of reinforcement, concrete, rolled steel);

- concrete strength;

- installed fittings do not correspond to the design, and the interface units, embedded parts and fasteners are destroyed or damaged.

The minimum permissible values of the controlled (determining) parameters in formulas (3) and (4) are established according to the results of calculations of building structures using the known methods of building mechanics and material resistance to determine the bearing capacity and compare it with the maximum effective forces:

$$
F_{c r}\left[x_{1}(t), x_{2}(t), . ., x_{m}(t)\right]>F,
$$

where $F_{c r}\left[x_{1}(t), x_{2}(t), . ., x_{m}(t)\right]$ - the function of bearing capacity; $F$ is determined by the results of simplified calculations or mathematical modeling of the SSS of structures and the building as a whole.

The parameters $x_{1}(t), x_{2}(t), . ., x_{m}(t)$ are the dimensions of the cross section, the strength of the materials, including and as a function of time, deformation of the soil base, and the like. Determining the magnitude of the effective force $F$ for statically defined structures is not difficult from a fundamental point of view. For statically indefinable constructions, the value $F$ is determined by the results of mathematical modeling of the SSS established by the observation results.

The transition of inequality (5) to the equation indicates the exhaustion of the bearing capacity (resource) of the structure. Further operation is possible after reinforcement (replacement) or repair.

The calculation of the residual resource is performed in the following sequence $[4,5]$ :

1. Structural inspection is carried out and controlled parameters are established: cross-sectional dimensions, strength characteristics of materials, the size and nature of the loads and effects are specified.

2. The bearing capacity of the structure is determined according to the data of the observations $F_{c r}\left[x_{1}(t), x_{2}(t), . ., x_{m}(t)\right]$. Based on the calculation results, maximum efforts $F$ are established.

$$
F_{c r} \geq F
$$

are compared

If the inequality holds, the bearing capacity is not exhausted.

3. The residual life $t_{R}$ is determined using the assumption regarding the linear dependence of the change in controlled parameters on time:

$$
\begin{aligned}
& t_{R}=\Delta t \cdot \frac{F_{c r}-F}{F_{p r}-F_{c r}} ; \\
& \Delta t=t_{1}-t_{0},
\end{aligned}
$$


where $t_{0}$ - the operation commencement date of the structure (after manufacture, reinforcement or replacement) or preliminary examination, year; $t_{1}$ - the date of the observation and the establishment of changes in the controlled parameters, year; $F_{p r}$ - the bearing capacity of the element, which is determined by the design data.

The determination of the residual resource should be carried out, if possible, on a larger basis (8). More precisely, a decision regarding the size of the resource can be obtained subject to the results of regular observations and definitions of controlled parameters and technical condition.

If inequality (6) is not satisfied, the element is in a state unsuitable for operation or in emergency.

In the presence of uneven base sediments, as well as during high-temperature influences, it will be advisable to carry out mathematical modeling, established by the results of a SSS observation of the structures and the building as a whole.

\section{SWOT analysis of research results}

Strengths. The positive effect of applying the proposed methodology for determining the residual life of individual structures, buildings and structures as a whole can be considered the possibility of extending the life of the operation or performing reinforcement or replacement of structures. Reliability and durability of buildings in the process of construction should be ensured through the use of high-quality materials, compliance with the technology of work and full compliance with their design. Changes in controlled parameters under the influence of various factors during operation can lead to structural failure. Since most of the factors affecting the durability of buildings and structures are random in nature, therefore, the reliability and durability of building structures are determined by the laws of probability theory.

Weaknesses. The weakness of the developed methodology for determining the technical condition and residual life of structures is the significant dependence of the results of continuous monitoring, diagnostics of structures and soil of the base on the instruments used and design features.

It is necessary to regularly monitor the technical condition of building structures, buildings and structures at various stages of their life cycle: design, construction, operation, conservation, re-conservation, liquidation.

Opportunities. The forecast of changes in the parameters of the technical condition and residual life will make it possible to predict current and overhaul repairs of structures, to exclude losses from accidental destruction of structures. The basis of the organization of monitoring to ensure the operational safety of buildings and structures is to monitor changes in indicators of controlled parameters of the technical condition and assess certain changes. The number and types of monitored parameters are determined by the monitoring program, the requirements of regulatory and design documentation, and the conditions for maintaining the operational properties of an object during its life cycle.

The proposed methodology for determining the technical condition and residual life of structures of buildings and structures can also be applied during the elimination of non-design impacts on structures (natural disasters, industrial accidents, etc.).

Threats. The complexity of the implementation of the research results lies in the need for significant investment in the development of a monitoring program, staff training and the purchase of modern instruments and equipment for structural diagnostics. In modern specialized construction testing laboratories, capital costs can be minimized.

\section{Conclusions}

1. General requirements for monitoring the technical condition of structural elements, buildings and structures have been developed. In general, monitoring of construction sites is a system of monitoring their technical condition, receiving and transmitting information to services that are responsible for the safety of facilities. It is an independent element of the scientific and technical support of objects in the process of their construction and operation, ensures the reliability of construction objects and allows to predict their durability.

The basis of the organization of monitoring to ensure the operational safety of buildings and structures is monitoring of the changes in indicators of state parameters and assess certain changes. The number and types of controlled parameters are determined by the results of a previous observation, the requirements of regulatory and design documentation, the conditions for maintaining the operational properties of an object during its life cycle.

Reactions of changes in the technical condition of structural elements are recorded by sensors of the monitoring system, which allow to obtain data on the reaction of the object to external and internal influences, namely:

- movement of the object and individual elements in space in the form of deflections, sediments, rolls and the like;

- deformation in building structures;

- changes in the dynamic characteristics of building structures and the building as a whole;

- changes in the environment surrounding the monitoring object.

Continuous monitoring of the technical condition of buildings and structures using automated systems is organized on structures and buildings that are responsible for safety criteria. In this case, instruments and equipment are used with automatic storage, processing and transmission of measurement results through information communication channels.

The reliability of the obtained results must be ensured by the application of standardized methods for conducting research and determining controlled parameters, relevant instruments, equipment and measuring instruments.

As criteria for failures and damage, the limiting values of the parameters of the technical condition (the presence or absence of cracks, the width of the opening of cracks, deflections, displacements, strength and deformability of structural materials, etc.), which are usually set by design or regulatory documentation, should be considered.

2. Methods have been developed for calculating the stress-strain state and assessing the state of structures that have received defects and damage during operation. The strength of the structures of buildings and structures directly depends on the strength of the materials used (concrete, reinforcement), the location of the reinforcement in the section, as well as on loads and effects.

The mathematical model of the building (or its automated analogue in the information system) makes it possible to carry out operational preliminary forecasting of the values 
of the controlled parameters of building structures. The result of the previous operational forecast is the conclusion about the operational suitability of controlled building structures, taking into account a possible tendency to worsen their technical condition. The forecast for the output of the recorded values of certain parameters of building structures of the limit of a given criterion is the basis for making decisions on the possibility of further operation of a building or structure.

3. Methods have been developed for determining the residual life of structures of buildings and structures based on monitoring results.

Determination of the residual life of structures of buildings and structures is carried out on the basis of data obtained as a result of monitoring. According to the results of the analysis of technical documentation, visual and instrumental examination, a preliminary assessment of the technical condition of structures, buildings and structures as a whole is carried out and a conclusion is made about the need for mathematical modeling of SSS or simplified structural calculations. A preliminary assessment of the technical condition is based on the evaluation criteria. The forecast of changes in the technical condition during further operation is carried out on the basis of the analysis of degradation processes and the identification of the compliance of the actual parameters of the technical condition with the requirements of design and regulatory documentation.

A methodology for calculating the residual resource of the structures of buildings and structures based on data obtained during monitoring is presented.

\section{References}

1. DSTU-N B V.1.2-18:2016. Nastanova shchodo obstezhennya budivel' $i$ sporud dlya vyznachennya ta otsinky yikh tekhnichnoho stanu (2017). Kyiv: DP «UkrNDNTs», 45

2. DSTU-NB V.1.2-17:2016. Nastanova shchodo naukovo-tekhnichnoho monitorinhu budivel' $i$ sporud (2017). Kviv: DP «UkrNDNTs», 38

3. DBN B.1.2-14:2018. Sistema zabezpechennia nadiinosti ta bezpeki budivelnih ob'ektiv. Zagalni principi zabezpechennia nadijnosti ta konstruktivnoi bezpeki budivel', sporud, budivelnih konstrukcii ta osnov (2018). Kyiv: Minrehion Ukrayiny, 30.

4. Holodnov, O., Gordiuk, M., Tkachuk, I, Semynoh, M. (2015). Opredelenie ostatochnoho resursa izhibaemih elementov posle razlichnih vozdeistvii. Zbirnyk naukovykh prats' Ukrayins'koi dergavnoi akademii zaliznichnogo transportu, 151, 94-102.

5. Otroch, Yu., Ivanov, A., Holodnov, O. (2011). Komplex vzaemozviazanih zahodiv shchodo viznachennia parametriv naprugenodeformovanogo i tehnichnogo stanu konstrukcii pri riznih vplivah. Zbirnyk naukovykh prats' Ukrayins'koho instytutu stalevykh konstruktsiy imeni V. M. Shymanovs'koho, 8, 98-109.

6. Larocca, A. P. C. (2014). Dynamic Monitoring vertical Deflectionof Small Concrete Bridge Using Conventional Sensors And $100 \mathrm{~Hz}$ GPS Receivers - Preliminary Results. IOSR Journal of Engineering, 4 (9), 9-20. doi: http://doi.org/10.9790/3021-04920920

7. Gaidaichuk, V., Kotenko, K., Kedyk, I. (2018). Development of theoretical and experimental dynamic monitoring of large-scale building structure. Technology Audit and Production Reserves, 1 (2 (39)), 38-45. doi: http://doi.org/10.15587/2312-8372. 2018.123463
8. Wendner, R., Hubler, M. H., Bažant, Z. P. (2015). Statistical justification of model B4 for multi-decade concrete creep using laboratory and bridge databases and comparisons to other models. Materials and Structures, 48 (4), 815-833. doi: http:// doi.org/10.1617/s11527-014-0486-1

9. Abdel-Fttah, A., Said, M., Salah, A. (2016). Nonlinear finite element analysis for reinforced concrete slabs under punching loads. International Journal of Civil Engineering and Techno$\log y, 7$ (3), 392-397.

10. Hubler, M. H., Wendner, R., Bažant, Z. P. (2015). Statistical justification of Model B4 for drying and autogenous shrinkage of concrete and comparisons to other models. Materials and Structures, 48 (4), 797-814. doi: http://doi.org/10.1617/ s11527-014-0516-z

11. Balomenos, G. P., Genikomsou, A. S., Polak, M. A., Pandey, M. D. (2015). Efficient method for probabilistic finite element analysis with application to reinforced concrete slabs. Engineering Structures, 103, 85-101. doi: http://doi.org/10.1016/ j.engstruct.2015.08.038

12. Fraile-Garcia, E., Ferreiro-Cabello, J., Martinez-Camara, E., Jimenez-Macias, E. (2016). Optimization based on life cycle analysis for reinforced concrete structures with one-way slabs. Engineering Structures, 109, 126-138. doi: http://doi.org/10.1016/ j.engstruct.2015.12.001

13. Lantsoght, E. O. L., van der Veen, C., Walraven, J., de Boer, A. (2015). Experimental investigation on shear capacity of reinforced concrete slabs with plain bars and slabs on elastomeric bearings. Engineering Structures, 103, 1-14. doi: http://doi.org/ 10.1016/j.engstruct.2015.08.028

14. Einpaul, J., Ospina, C. E., Fernández Ruiz, M., Muttoni, A. (2016). Punching shear capacity of continuous slabs. ACI Structural Journal, 113 (4), 861-872. doi: http://doi.org/10.14359/51688758

15. Caldas, R. B., Fakury, R. H., Sousa Jr., J. B. M. (2014). Finite element implementation for the analysis of 3D steel and composite frames subjected to fire. Latin American Journal of Solids and Structures, 11 (1), 1-18. doi: http://doi.org/10.1590/ s1679-78252014000100001

16. Vatulia, G., Orel, E., Kovalov, M. (2014). Evaluation of steelconcrete beams fire resistance with the selection of effective fire protection. Proceedings of the 6th International Conference on Dynamics of Civil Engineering and Transport Structures and Wind Engineering. Zilina, 327-331.

Gordiuk Mykola, Limited Liability Company «V. Shimanovsky Ukrainian Institute of Steel Construction», Kyiv, Ukraine, ORCID: http:// orcid.org/0000-0003-0517-9612,e-mail: gordiyk@ukr.net

Semynoh Mykola, Limited Liability Company «V. Shimanovsky Ukrainian Institute of Steel Construction», Kyiv, Ukraine, ORCID: http:// orcid.org/0000-0002-8633-5041, e-mail: semynog_mm@ukr.net

Holodnov Oleksandr, Doctor of Technical Sciences, Professor, Limited Liability Company «V. Shimanovsky Ukrainian Institute of Steel Construction», Kyiv, Ukraine, ORCID: http://orcid.org/0000-00029722-9164, e-mail: golodnow@ukr.net

Tkachuk Igor, Limited Liability Company «V. Shimanovsky Ukrainian Institute of Steel Construction», Kyiv, Ukraine, ORCID: http:// orcid.org/0000-0002-6587-8354, e-mail: i.tkachuk@owe.com.ua

Ivanov Boris, Chief Project Engineer, MegaBP LLC, Kyiv, Ukraine, ORCID: http://orcid.org/0000-0002-9203-2987, e-mail: ivanov@megabp.com 